between the United Kingdom Government, the Hong Kong Government and the University authorities on detailed proposals for reconstruction. The recent gift thus raises the total sum for capital expenditure to the scheduled minimum of $£ 500,000$.

\section{Automatic Control: Conference at Cranfield}

A CoNFERENCE on "Automatic Control", arranged under the auspices of the Department of Scientific and Industrial Research, will be held at the College of Aeronautics, Cranfield, Beds, during July 16-21, and will be formally opened by Sir Ben Lockspeiser, secretary of the Department. The Conference will thus follow on immediately after the instrument exhibition (July 4-14) at Olympia, London. The purpose of the Conference is to review the most recent advances in the whole field of automatic control, from research work on fundamentals to industrial applications in process control, and an exhibition of equipment, with demonstrations, will be held concurrently. Leading workers from European countries and the United States, as well as from Great Britain and the Commonwealth, will be participating. The programmo mainly consists of a number of papers, there being four sessions a day with a maximum of three papers presented at each, and authors will only briefly introduce their papers, the major portion of each session being devoted to discussion. The opening paper will be by Prof. G. S, Brown, professor of electrical engineering and director of the Servomechanisms Laboratory, Massachusetts Institute of Technology. Two evening sessions have been arranged on automatic control within the human body and on the application of closed-loop theory to economic problems. Membership of the Conference is limited to 250 , and accommodation will be at the College. All arrangements should be made not later than April 30. Further details can be obtained from the organizing secretary of the Conference on Automatic Control-1951, Department of Scientific and Industrial Research, Charles House, 5-11 Regent Street, London, S.W.1.

\section{Summer Course in Food Science}

A summer course in food science will be held in the University of Cambridge, in co-operation with the Department of Scientific and Industrial Research, at the Low Temperature Research Station, during August 13-28. During the first ten days the course will cover the ground of that held in 1948 ; during the second week recent advances and special topics will be dealt with. Provisional registration for the whole course, or for the second part only (which is open to those who have attended the previous course), may now be made in writing to G. F. Hickson, Secretary, Board of Extra-Mural Studies, Stuart House, Cambridge. A detailed syllabus will be available later.

\section{Chemical Society: Officers}

THE annual meeting of the Chemical Society was held on March 21, when elections to the Council were made. The present officers of the Society are : President, Prof. E. K. Rideal ; Vice-Presidents who have filled the office of president, Prof. F. G. Donnan, Sir Ian Heilbron, Sir Cyril Hinshelwood, Dr. W. H. Mills, Sir Robert Robinson and Prof. N. V. Sidgwick; Vice-Presidents, Prof. G. R. Clemo, Prof. J. W. Cook, Prof. D. H. Hey, Prof. R. P. Linstead, Prof. M. Stacey and Prof. W. Wardlaw; Treasurer, Sir Wallace Akers; Secretaries, Dr. H. Burton, Prof. E. D. Hughes and Dr. L. E. Sutton.

\section{The Night Sky in April}

NEW moon occurs on April 6d. 10h. 52m., v.T., and full moon on April $21 \mathrm{~d}$. $21 \mathrm{~h}$. $30 \mathrm{~m}$. The following conjunctions with the moon take place: April 5d. 00h., Jupiter $2^{\circ}$ S.; April 7d. 12h., Mars $4^{\circ}$ S.; April 8d. 02h., Mercury $1^{\circ}$ S.; April 9d. 13h., Venus $4^{\circ} \mathrm{S}$; ; April 19d. 14h., Saturn $4^{\circ} \mathrm{N}$. In addition to these conjunctions with the moon, Mercury is in conjunction with Mars on April 19d. 08h., Mereury being $2 \cdot 8^{\circ} \mathrm{N}$. At the beginning of the month Mercury sets at $20 \mathrm{~h} .15 \mathrm{~m}$., about an hour and three-quarters after sunset, and can be seen in the western sky; but after the middle of the month it gradually draws too close to the sun for favourable observation, attaining inferior conjunction on April 25, and then it becomes a morning star but too close to the sun to be seen during the remainder of April. Venus is an evening star, setting at $21 \mathrm{~h} .30 \mathrm{~m} ., 22 \mathrm{~h} .15 \mathrm{~m}$. and $23 \mathrm{~h}$. $0 \mathrm{~m}$. on April 1, 15 and 30, respectively, and is conspicuous in the western sky for some hours after sunset, with stellar magnitude $-\mathbf{3 . 4}$ and the visible portion of the illuminated disk varying between $0 \cdot 83$ and 0.74. Mars sets an hour after the sun on April 1, but draws closer to the sun during the month and is unfavourably placed for observation. At the beginning of the month Jupiter rises fifteen minutes, and at the end of the month a little less than an hour, before sunrise, but is rather close to the sun throughout April for favourable observation. Saturn is visible throughout the night, setting at $5 \mathrm{~h} .35 \mathrm{~m}$., 4h. $40 \mathrm{~m}$. and $3 \mathrm{~h}$. $40 \mathrm{~m}$., on April 1,15 and 30 , respectively, and is a little east of $\beta$ Virginis in the early part of April but approaches the star later in the month. No occultations of stars brighter than magnitude 6 occur during April. The Lyrid meteors, due on April 18 and for about a week afterwards, will be difficult to observe owing to moonlight.

\section{Announcements}

The Lister Medal for 1951 has been awarded to Sir James Learmonth, in recognition of his distinguished contributions to surgical science. Sir James Learmonth will deliver the Lister Memorial Lecture in London, on April 4, 1952, under the auspices of the Royal College of Surgeons of England. This is the tenth occasion of the award, which is made by a committee representative of the Royal Society, the Royal College of Surgeons of England, the Royal College of Surgeons in Ireland, the University of Edinburgh and the University of Glasgow.

A symposium on crop protection will take place this year in the State Agricultural College, Ghent, on April 24. Dr. A. Balachowsky, of the Institut Pasteur, Paris, will give a lecture entitled "Sur les Rapports entre la Lutte chimique et la Lutte biologique", and several Dutch and Belgian specialists will also be participating. Further details can be obtained from Prof. J. van den Brande, at the State Agricultural College, Ghent.

THE Manchester College of Technology is offering six scholarships and six exhibitions, varying in value up to $£ 140$ a year plus approved fees and tenable for three years in one of the full-time day courses of the College. An Edmund Mills Harwood Memorial Scholarship in engineering, of $£ 50$ a year for three years, is also being offered. Application forms for these awards must be returned by June 1 . Further particulars can be obtained from the Registrar, College of Technology, Manchester 1. 